\title{
TYPHOONS AND DROUGHTS: FOOD SHORTAGES AND FAMINE IN THE PHILIPPINES SINCE THE SEVENTEENTH CENTURY
}

JAMES F. WARREN

Asia Research Institute and School of Arts,

Murdoch University

\section{Abstract}

In this paper, I explore why so many people have starved in the Philippines when typhoons, floods and droughts have occurred since the seventeenth century and governments of the day have been unable to provide relief. Why, in the twenty-first century, are millions of Filipinos still living in the shadow of hunger? I draw attention to the causes and consequences of food shortages and famine and the relationship between climatic and weather factors, especially storms, floods and drought, and food supply (ownership and exchange), regional characteristics and social structure. In examining famines over time, I stress the structural links between food shortages, the nature of Filipino peasant societies and the weather factor. In addition, I explore the developing historical relationship between economic and political changes and societal group inequality, involving the loss of entitlements that become more explicit in times of famine. I also examine the lingering impacts of climate variability and extreme weather-typhoons, floods and drought-linked to past and present famines. Filipino farmers have not vanquished famine. Destitution and death from disasters and famine were all continual and familiar experiences under both Spanish and American rule, and remain so to the present day.

Keywords: famine, Philippines, typhoons, food supply, peasant societies

\section{Introduction}

Until recently, scholars of the Philippines have largely ignored the subject of famine and starvation and its links to the impacts of major weather events. Consequently, only a limited effort has been made to understand the causal relationship between starvation in the Philippines and famines, and their historical bases and social and 
behavioural effects. ${ }^{1}$ In this paper, I will draw attention to the causes and consequences of food shortages and famine and the relationship between climatic and weather factors, especially storms, floods and drought, and food supply (ownership and exchange), regional characteristics and social structure. ${ }^{2}$

\section{Definition of famine}

Famine is defined as a shortage of food 'so extreme and protracted as to result in widespread persistent hunger, notable emaciation ... and a considerable elevation of community death rate'. ${ }^{3}$ David Arnold's definition emphasises its exceptional characteristics. Famine is, he argues:

a collective catastrophe of such magnitude as to cause social and economic dislocation. It generally results in abnormal levels of destitution, hunger and death $\ldots$ and can lead to the complete disintegration of customary patterns of work and subsistence and ... [can] greatly disrupt customary norms of work mortality and social behavior. ${ }^{4}$

While famine is exceptional, Arnold notes it is closely linked to economic and political structures and the vagaries of nature. Famine also has major demographic consequences, including excess mortality, often caused by epidemics linked to hunger, a decline in birth rate and increased migration. ${ }^{5}$

Entries giving historical usages for food in early dictionaries, like Lisboa's classic 1628 work, Vocabulario de la Lengua Bicol, reveal how people in southern Luzon suffered periods of extreme hardship when typhoons and floods reduced the supply of food. ${ }^{6}$ Lisboa defined tingating as 'an extended dry season before the rains return', suggesting the possible adverse effects of a prolonged drought. Terms pertaining to food scarcity suggest the Bikol region experienced famine from time to time, and that its people went hungry in the seventeenth century. Malcolm Mintz notes that

1 Important research has been done recently by Linda A. Newsom, Conquest and Pestilence in the Early Spanish Philippines (Honolulu: University of Hawai' i Press, 2009), 73, 77, 83, 88, 106-7, 165, 197 and 211; Luis Camara Dery, Pestilence in the Philippines: A Social History of the Filipino People, 1571-1800 (Quezon City: New Day Publishers, 2006). Dery mentions instances of drought and famine in various provinces between the sixteenth and eighteenth centuries; Norman G. Owen, 'A subsistence crisis in the provincial Philippines 1845-1846', in The Bikol Blend: Bikolanos and their History (Quezon City: New Day Publishers, 1999), 39-47.

2 Robert Dirks, 'Social responses during severe food shortages and famine', Current Anthropology 21, no. 1 (1980): 21-44; M. K. Bennett, 'Famine', in International Encyclopedia of the Social Sciences, ed. David L. Sills (New York: Macmillan and the Free Press, 1968), 5: 322-6.

3 Bennett, 'Famine', 322.

4 David Arnold, Famine, Social Crisis and Historical Change (New York: Basil Blackwell, 1988), 6-7.

5 ibid., 6-7.

6 For a discussion on this, see Malcolm Mintz, 'Food', in The Philippines at the Turn of the Sixteenth Century with Particular Reference to the Bikol Region, monograph 1, in Intersections: Gender and Sexuality in Asia and the Pacific (Canberra: The Australian National University, 2011), intersections.anu.edu.au/monograph1/mintz_food.html, accessed 19 July 2013; and Bikol Dictionary, vol. 1 English-Bikol Index (Perth: Indonesian/Malay Texts and Resources, 2004), 181, 221. 
Lisboa's entry for hawad refers to offering linsa, edible taro, to the starving or dying during a time of food scarcity; hence linsa lamang an nakakhawad samuya, or 'only taro is keeping us alive'. Indeed, it is from entries like halop, 'famished, very hungry', and pinahugan, 'to let people starve to death by not cooking for them or looking after them', ' that we discover that a Bikolaño in the early Spanish period had barely enough food to keep body and soul together in a time of famine.

\section{Causes of famine in the Philippines}

Climatic variability has been one of the principal sources of fluctuations in food production in the archipelago, particularly in the semi-arid, flood-prone parts of the country. Climatic variability has magnified and contributed to hunger, famine and social dislocation, but from the standpoint of the individual peasant in the Philippines, famine must be seen not as an absolute scarcity of food in particular regions, but rather as a loss of one's entitlements to food and/or the means of subsistence.

The identity of past and present famine-generating agents in the Philippines needs to take account of both the 'supply side' (Malthusian, climatic or ecological factors) and the 'demand side' (entitlements or market failure) explanations. ${ }^{8}$ Severe food shortages of the past in the archipelago were often not due to a lack of food in the area of the famine. For example, rice was being exported from Pampanga to Manila in the same years of the sixteenth century that starving Pampangueños were being forcibly taken off their land to work in the gold mines of Ilocos, or conscripted to cut timber for the construction of the Manila galleons meant to bring the porcelain and silk of China to the inhabitants of the New World. ${ }^{9}$

Further, Amartya Sen has argued that severe food shortages and famines are triggered by either a rise in the price of food and/or a fall in the 'exchange entitlements'namely, the food that one could normally obtain by any combination of buying or growing food, or receiving it as payment for rent, interest or wages. ${ }^{10}$ These crises should be examined in tandem with the large-scale interruptions of subsistence caused by typhoons, floods and drought, to highlight the fact that they have an economic basis in the process of production. The political and economic institutions - the structure, organisation and methods-imposed by the Spanish

\footnotetext{
7 Mintz, 'Food'.

8 George Caffentzis, 'On the notion of a crisis of social reproduction: a theoretical review', The Commoner, no. 5 (Autumn, 2002): 3.

9 Letter from Fray Domingo de Salazar, Manila, to King Philip II, 1383, in The Philippine Islands, 1493-1898, ed. Emma Blair and James Robertson (Mandaluyon, Rizal: Cachos Hermanos, 1973), 5: 212-21; John A. Larkin, The Pampangans: Colonial Society in a Philippine Province (Berkeley, CA: University of California Press, 1972), 25. 10 Amartya Sen, Poverty and Famines: An Essay on Entitlements and Deprivation (Oxford: Clarendon Press, 1981), vii-ix, 1-8, 24-38.
} 
colonial government radically changed the 'primitive economy' and livelihood systems, as well as indigenous hazard management, in the sixteenth and seventeenth centuries. ${ }^{11}$

The Spanish crown asserted its right to tribute, and the right of the colonists to maximise profits. The collection of tribute payments through the encomienda, the exploitation of labour under the polos system, and the compulsory sale and requisitioning of local products like rice, under quotas set by the vandala, placed enormous strains on the traditional subsistence economies of the pacified barangays. During the reign of Philip II, this system of requisitioning, compulsory sales and fixed quotas caused severe economic hardship and food shortages as the rural worlds of Luzon and the Visayas became tied to the consumption-oriented mercantile economy of the Spanish Empire. ${ }^{12}$ In 1592, the Spanish waged total war by 'fire and sword' by destroying crops around Pampanga. According to an official letter sent to Philip II, many died in the famine that followed because of the forced deliveries of rice taken away from the villages of Pampanga and use of scorched-earth tactics. ${ }^{13}$

Two centuries later, the Spanish faced the nineteenth-century challenge of integration with competitive globalised markets, and increasingly diverted farming from diversified production to monocrop economies. When the galleon trade ended in 1815 , Spain was determined to develop agricultural productivity by pushing farming into export-oriented cash-crop production. The Spanish government opened Philippine ports to international markets and trade creating new wealth, as well as severe poverty and hunger.

\section{The nature of Filipino peasant societies and the weather factor}

Mike Davis, in Late Victorian Holocausts, has noted that the vulnerability of tropical agriculturalists like Filipino peasants to climate variability and extreme weather events was exacerbated by their integration into regional production systems and world commodity markets. ${ }^{14}$ Beginning in the nineteenth century, the incorporation of Filipino peasants and smallholder producers into commodity and financial circuits controlled from overseas tended to undermine rural subsistence and traditional food security in households and villages throughout the Philippines. Ecological

11 Germelino M. Bautista, 'The economy of the Philippines in the age of Philip II (1527-1598)', in Re-shaping the World: Philip II of Spain and his Time, ed. Damaso De Lario (Quezon City: Ateneo de Manila University Press, 2008), 34-40.

12 Bautista, 'The economy of the Philippines in the age of Philip II', 54.

13 Letter from Fray Domingo de Salazar, Manila, to King Philip II, 1583, in The Philippine Islands, ed. Blair and Robertson, 5: 188-91. An earlier, similar letter, of 20 June 1582, also exists on file.

14 Mike Davis, Late Victorian Holocausts: El Niño, Famines and the Making of the Third World (London: Verso, 2001), 288-92. 
poverty, defined as the loss of entitlement to the natural resource base of traditional agriculture, constituted part of a causal triangle with increasing household poverty and state decapitation: the nature of this triangle, according to Davis, helps explain both the emergence of a 'third world' situation in the Philippines, and its increasing vulnerability to typhoons and drought-induced food shortages and famines. ${ }^{15}$

Pitirim Sorokin, in a systematic and objective analysis of the impacts of famine and pestilence on social life, claims that calamity is often a constant factor in most societies or regions of the world. ${ }^{16}$ In the Philippines, food scarcity, pestilence and trauma, sometimes following or proceeding typhoons and drought that seem to have occurred in cycles of intensity, were prevalent in the early Spanish period in certain parts of the archipelago. ${ }^{17}$ Northern Luzon has suffered most, but also areas of southern Luzon and Samar have been historically vulnerable. ${ }^{18}$

Sorokin noted that natural calamities affected different persons, different cultures and different segments of the same culture in varying ways. ${ }^{19}$ Unsurprisingly, when famine struck, the symptoms of malnutrition and financial ruin were first evident among the poor. ${ }^{20}$ Serious food shortages and famine were frequent in Luzon and the eastern Visayas. Even in better times, rural people were still at risk, their afflictions typically a shrinking agricultural base in a subsistence economy, endemic poverty and a growing proportion of their population malnourished. A shortage of arable land had led to overuse, soil degradation and tenant farming. Historically, the combination of these important factors and extreme weather has led to hunger. For example, the poor harvests of the late 1790s and the late 1990s meant the vulnerable on Luzon, the Visayas and Mindanao became desperate and displaced as famine loomed. In remote corners, the chronic hunger soon led to starvation. Exhausted, skeletal people, more often children and the elderly, were first to die. The concentration of wealth and power in the hands of a few in these regions led, as early as the seventeenth century, to a series of rural crises, with severe food shortages and local famine.

These subsistence crises were not just due to a natural hazard, but rather were also the result of social, economic and political factors that in fact turned any natural disaster into a sociopolitical disaster. While there undoubtedly exist some moral economy and resilience embedded in kinship structures and core spiritual values in the Philippines, the reality of famine threatens 'moral and social collapse'. ${ }^{21}$

15 Davis, Late Victorian Holocausts, 310.

16 Pitirim A. Sorokin, Man and Society in Calamity: The Effects of War, Revolution, Famine, Pestilence upon Human

Mind, Behavior, Social Organization and Cultural Life (New York: E. P. Dutton, 1942), 9-10, 13-15, 288-9, 293.

17 See Newsom, Conquest and Pestilence, 24-52, 251-64.

18 Charles H. Forster, 'Relief problems of the 7,083 Philippine Islands', in the Red Cross Courier, 1 January 1927,

$13-15$.

19 Sorokin, Man and Society in Calamity, 14-15, 158-64.

20 ibid., 14-15, 158-64.

21 Arnold, Famine, Social Crisis and Historical Change, 82. 
The progressive development of the locus of famine in typhoon-prone regions is linked directly to Western colonial penetration and the advent of integrated international circuits of capital, markets and commodity flows in the Philippines. Emergent, vulnerable subsistence-based populations in Pampanga, Bikol and Samar began to participate in a global economy over which they exercised no control. In such an environment, control of the means of production and distribution of food meant power under colonial rule, and those powerful individuals-officials, clergy, rice merchants and landlords-could manipulate and profit from regional and class-based famines. Inequality of access to food is historically evident in typhoon or drought-prone regions, because of early monopoly practices and later laissez-faire economics and development within the Philippines and with Spain and the United States.

To understand the causes of hunger and explain the unequal effects of severe famine in historical perspective for certain areas of the Philippines, it is necessary to explore the way rice (the staple food) is central to the process.

\section{Rice}

Rice, or palay, was/is the staple food and principal source of sustenance for the majority of Filipinos. More than 120 varieties of this grain exist, which are always eaten with fish or some type of meat. ${ }^{22}$ Rain-fed lowland rice is grown in 14 regions of the Philippines, and constitutes about 44 per cent of the total rice area and 81 per cent of the total rain-fed key rice-producing areas. ${ }^{23}$ Paradoxically, the very success of rice as a quintessential staple to feed a rising population from the late eighteenth century in the Philippines also meant that a growing proportion of the society depended upon the consumption of this singular food to a very large extent for food security. ${ }^{24}$

It was possible for the Filipino peasant to harvest twice within a year on a small plot of ground because of the exceptional fertility of the soil and favourable climate. At the same time, root crops, including taro (Colocasia esculenta) and the camote (sweet potato) were already cultivated on a widespread basis in the Visayas by the

22 'State of agriculture', Paper XI, Report of the Philippine Commission to the President (Washington, DC: Government Printing Office, 1901), 4: 11; William Henry Scott, Barangay: Sixteenth Century Philippine Culture and Society (Quezon City: Ateneo de Manila University Press, 1994), 36-9; Frederick L. Wernstedt and J. E. Spencer, The Philippine Island World (Berkeley and Los Angeles, CA: University of California Press, 1967), 82.

23 R. T. Cruz and J. F. Fabiosa, 'Drought problems in rainfed lowland rice in the Philippines', in Breeding Strategies for Rainfed Lowland Rice in Drought-prone Environments, ed. S. Fukai, M. Cooper and J. Salisbury (Canberra: Australian Centre for International Agricultural Research, 1997), 58.

24 Fernand Braudel, The Structures of Everyday Life: Civilization and Capitalism 15th-18th Century (New York: Harper and Row, 1981), 1: 152-3. 
late 1660s. ${ }^{25}$ When typhoon damage and drought created severe food shortages for those who grew rice, these root crops became, in the words of Ignacio Francisco Alcina SJ, the 'refuge of the poor'. ${ }^{26}$

Pampanga and Pangasinan over the centuries became known as the rice bowl of the Philippines. Indeed, rice grown in the central plain of Luzon and in the south-east part of the island helped feed the expanding populations of the Chinese Empire and the colonial Philippines, and by the second half of the nineteenth century the archipelago became one of Asia's largest rice exporters. ${ }^{27}$ But, as the nineteenth century progressed, the rice paddy infrastructure was increasingly degraded or neglected as farmers were encouraged to plant cash crops of abaca, copra, tobacco and sugar, and were often forced to sell rice below market prices.

Throughout the Spanish period, the majority of Filipinos embraced palay, or hulled rice, as their key dietary staple. But by the early twentieth century, the Philippines exported her rice primarily to the China coast, and her poor lived almost exclusively on imported rice, tubers and corn. By 1912, the control of the price and supplies of rice became a major concern to the United States Government. In the previous decade, marked by war and upheaval and the transition to American rule, the production of rice could not meet Filipino needs and the archipelago became alarmingly dependent on a foreign supply of rice. ${ }^{28}$ In 1912, 5,656,636 cavanes $(339,338,160 \mathrm{~kg})$ of rice were produced, but more than four-and-a-half times that tonnage, $26,017,012$ cavanes $(1,561,020,720 \mathrm{~kg})$, had to be imported during the unprecedented drought of $1911-12 .{ }^{29}$

This trend has continued since the Second World War because the large rural sector, which has remained essentially traditional in outlook, has struggled to increase agricultural output as the post-war population has increased. The problem of demand for rice exceeding supply that applied at the start of the twentieth century still applies into the twenty-first century. The Philippines may now be one of the world's largest importers of rice, buying to feed a population above 102 million with one of the world's fastest annual demographic growth rates. ${ }^{30}$

25 Scott, Barangay, 39

26 Francisco Alcina SJ, cited in Scott, Barangay, 43.

27 See Norman G. Owen, 'The rice industry of mainland Southeast Asia, 1850-1914', Journal of the Siam Society 59 (July 1971): 75-143.

28 'Report of the Executive Secretary, September 16, 1912', in Report of the Philippine Commission to the Secretary of War, 1912 (Washington, DC: Government Printing Office, 1913), 39.

29 'Report of the Secretary of Finance and Justice', in Report of the Philippine Commission, 208.

30 Philippines Population, 29 October 2016: countrymeters.info/en/Philippines, accessed 29 October 2016; Jonathan Watts, 'The human price of rice', Guardian Weekly, 13 June 2008, $25-6$. 


\section{Vulnerable regions: Cash crops and food shortages}

Just one destructive typhoon each year in the cash-crop producing regions of the Philippines could make the lives and prospects of the inhabitants of several provinces extremely grim for months, if not years. It takes several months for palay to ripen, up to eight to 10 months for abaca to be ready for harvesting, and between seven and 10 years for a coconut tree to bear fruit. ${ }^{31}$ Consequently, over several centuries, subsistence farmers, who increasingly chose to cultivate cash crops, counting on a better standard of living, often found they had no visible means of sustaining themselves, because of the 'economic predicament' triggered by typhoons. Famine could not be averted.

Some dependent communities living along the typhoon belt developed common ideals and a sense of self-reliance in the midst of such calamity, but there were many others who depended on the crops for their daily sustenance-particularly in the seventeenth and eighteenth centuries. They succumbed to the fatalism arising from their inability to recover their economic losses. This situation was often far worse on the eastern side of the Philippines, in the so-called 'typhoon belt'.

There were areas of Luzon, the Visayas and Mindanao that were to be sorely tested by the recurrence of typhoons. Economic and ecological meltdown became a fact of life with the drift from a diversified to a monocrop economy. In the southern typhoon areas of the Visayas where copra and hemp were grown for export, farmlands no longer produced enough food for local consumption. Farmers purchased food from the profits of their cash crops. But when typhoon damage deprived them of their coconut and hemp harvests for at least two years, they faced the stark reality of food shortages, hunger and possible mass starvation. Without aid from a government calamity fund, cash-crop farmers were exposed to the hunger and health problems that accompany malnutrition. The same circumstances applied in the Cagayan Valley where tobacco was grown for export from the late eighteenth century.

The social costs of recurrent typhoons and drought-related famines in cash-crop regions, notably the Cagayan Valley and Samar, were high. Not surprisingly, people living in this difficult environment had made the least progress of any area of the Philippines at the start of the twentieth century. Large segments of the population were undernourished, and education and public works lagged behind the rest of the country. The people of the Cagayan Valley and Samar, situated at opposite ends of the archipelago, have found it more difficult to ride out the typhoon disasters and severe food shortages that have struck in tandem with such regularity.

31 'Lessons from typhoons', Manila Bulletin, 11 June 1998. 
During the early Spanish period, Jesuit letters mention crop failures due to typhoons, as in 1610, when famine struck the island of Bohol:

This year we established a hospital to which we brought many who had fallen sick because during the recent famine they ate wild fruit and the leaves of trees, and whatever they could lay their hands on. We shared whatever food we had in the house with them and with many others lying about in the streets and houses. ${ }^{32}$

The Jesuits had learned early that typhoons could readily turn large areas of the Visayas into places of appalling stress, fear, starvation and death. Fr Juan Delgado, writing about the 'religious conditions of the islands', wrote that various religious orders had made strong protestations to the Crown to regulate the price of rice on behalf of the Visayans:

Five or six years ago, on account of the representations made to the supreme government by the superiors of the religious orders, of the extreme poverty that the Indians were suffering because of the severe baguios and tempests-which had ruined their houses, fields and cocoa plantations, and even the churches and houses of the ministers - an order was issued by the said supreme government for rice, to be received in the Visayas at the price of three reals per fanega, which is the lowest among the natives. ${ }^{33}$

Despite this edict, the severe food shortages continued well into the next decade. A 1644 account revealed the bleak situation, noting the widespread scarcity of rice in the Visayas, as a ganta (equal to about $30 \mathrm{~mL}$ or $20 \mathrm{~g}$ ) of wheat rose from 2 to 20 reales. ${ }^{34}$

The November 1835 typhoon in Samar and Leyte caused famine, and in the process scattered people throughout the islands. In some ways the history of severe food shortage and famine on Samar is part of the inextricable history of typhoonand drought-related disasters, and the failure of local colonial authorities and the populace either to respond to or recover from such disasters. Fr Domingo Cabrejas describes the deplorable state of his mission due to a typhoon in November 1885, the flood, the ensuing misery and hunger, and requests for food aid and exemption from payment of tribute on behalf of his starving flock: they had 'been unable to eat for days at a time, and [were] living off small scraps and tubers'. The flood had left his mission in a state of 'total desolation' without rice or any other food. ${ }^{35}$

32 Horatio de la Costa SJ, The Jesuits in the Philippines, 1581-1786 (Cambridge, MA: Harvard University Press, 1967), 313.

33 Juan J. Delgado, 'Religious conditions of the islands', Historia General Sacro-profana Politica y Natural de las Islas Poniente Llamadas Filipinas (written in 1751-54), pp. 141-58, republished in The Philippine Islands, ed. Blair and Robertson, 28: 163-91.

34 Dery, Pestilence in the Philippines, 24.

35 Fr. Domingo Cabrejas a Senor Gobernador Capitan General, 18 May 1886. Calamidades Publicas (Baguios y Huracanes), no. 2, 1845-1898, F.460-461. National Archives of the Philippines (PNA). 
Just two years later, the military-political governor of the Visayas lodged a 59-page report on the consequences of a famine in the town of Gandara in Samar. The governor of Samar had distributed 27 cavanes of rice as emergency relief. Gandara was where expansion of trade and increasing agricultural exports, primarily abaca, had led to a decline in food production. Trade and exchange ties between coast and interior dwellers were strengthened, as the Samareños responded enthusiastically to the circulation of increased cash and credit by cultivating more abaca. ${ }^{36}$ However, the world demand for abaca fibre had an adverse effect on local food production in Gandara and elsewhere. Farmers in Gandara now looked after only their cash crops, especially abaca and fruit trees, neglecting to maintain their cultivation of rice and other sources of food. Consequently, rice yields began to steadily decline, sacrificed to the prospect of obtaining increased cash and credit derived from the monocrop economy. The endemic hunger, and indeed the famine, were direct consequences of the cumulative loss of the previous harvests, including the 1885 one, due to this neglect of their traditional livelihoods and the combined impacts of typhoons, floods and rat and locust plagues. ${ }^{37}$

The governor of Samar commented with ironic concern that at least 80 per cent of the arable land on the island remained uncultivated at this time by the little people'-tenants and itinerant labourers. Clearly, the entangled nature of crop requirements, especially abaca for export versus rice cultivation, and developing consumption patterns, both at the local and global level, helped sow the seeds of hunger in late nineteenth-century Samar.

\section{Typhoons and severe food shortage: Personal stories}

The eastern side of the Philippines was regularly hit by typhoons and tropical storms that strengthened over the warm waters of the Pacific before striking Cagayan, Isabella, Camarines Norte and Sur, Tayabas, Bikol, Leyte, Samar and northern Mindanao. Charles H. Forster, relying on the up-to-date meteorological research of the Manila Observatory, noted that typhoons seemed to occur in cycles of intensity. ${ }^{38}$ Consequently, typhoon-induced famine and pestilence were cyclical and targeted particular areas. Systematic data on the percentage and distribution of typhoons by province and the consequent effects of food shortages and famine are not available from earlier centuries, but some generalisations may be made. Using colonial and post-independence sources, it is possible to reconstruct the

36 Bruce Cruikshank, Samar: 1768-1898 (Manila: Historical Conservation Society, 1985), 208.

37 Don Pelayo Maria Chacon y Lopes, Gobernador Politico-Militar Samar a El Gobernador Capitan General,

31 January 1887. Calamidades Publicas, 1863-1897, no. 5, exp. 201, F.422-424. PNA.

38 Forster, 'Relief problems of the 7,083 Philippine Islands', 13. 
devastation wrought by typhoons and drought upon these provinces. For me, this also becomes a wider inquiry into the relationship between the 'anatomy of disasters' and subsistence crises.

In February 1790, the alcalde mayor of Cagayan, Don Gregorio Ruano, opened a file to receive representations about the extreme food shortage, severe famine and high death toll that gripped his province in the years 1789-90. This compilation of evidence about the worst storm-related floods and consequent famine and epidemic to grip Ruano's province in decades was meant to bolster his urgent appeal for prompt aid. Several Dominican priests on the front line of the famine came before him and attested to the rapidly worsening state of affairs covering the entire province. Fr Thomas Figuerola, interim Provincial Vicar of the province, stated that the incessant typhoons and devastating floods that had occurred had destroyed not only the valuable cocoa crop, but also the people's palay and corn harvests, the 'usual sustenance of these natives' ${ }^{39}$

Most of his congregation had abandoned their fields and fled to the mountains in search of food and shelter, in order to survive, 'since these days the province is in a deplorable state'. ${ }^{40}$ In informing the royal officials of the utter state of misery of his province, the alcalde mayor highlighted the continuous nature of the typhoons that had occurred in recent years, totally wiping out the cocoa and corn crops. Four successive baguios had occurred, followed by destructive floods and the outbreak of famine, cholera and diarrhoeal diseases because of contaminated drinking water. Starving people by the hundreds were driven to the mountains, but the uplands became a killing ground. Ruano stated: 'They die within five or six days of eating grass and roots' and on such a scale 'that the mountain sides are littered with cadavers of Christians [sic] who died there of hunger' ${ }^{41}$

Ruano made no apologies to the Crown for the graphic manner of expression in his report. He felt compelled to relate how his days and nights started and finished with the door of his Casa Real being filled with hordes of desperate women with their children, begging for alms in a state of utter starvation and helplessness, because 'not only do they have nothing to eat, but rather they also have nothing with which to purchase food'. ${ }^{42}$ His strongly worded heartfelt plea for famine relief did not fall on deaf ears. Some rice from the king's stores in the provinces of Pangasinan and Ilocos-7-8,000 baskets_-was sent by sailing ship and entrusted to the alcalde to distribute to the worst-affected towns on a proportional basis. However, this food aid had to be paid for at cost and repaid within two years once the famine ended and

39 Don Gregorio Ruano to Governor Captain General Don Feliz Berenguer de Marguina, 6 April 1790, Ereccion de Pueblos - Cagayan 1751-1847. F. 167-196. PNA.

40 ibid.

41 ibid.

42 ibid. 
the inhabitants of Cagayan were able to harvest some crops. Payment would have to be made with either silver or in goods characteristic for payment of tribute in the province, such as cacao, corn or wax. ${ }^{43}$

In a different example, Fr Joseph Gaona, Dominican priest of the town of Tumanenos, and Fr Joseph de Santo Domingo Rodriguez of Nasiping wrote that the power of successive typhoons 'had ruined and uprooted everything that had been planted by these natives', noting how his parishioners kept themselves alive initially by eating the roots and stems of their fruit trees, but then went in search of similar trees and roots in the mountains. However, the time came when there were no more to be found. After that was when a 'fatal epidemic' spread across the entire province due to so many people rapidly dying from hunger and disease.

He recounted to his superior having witnessed starving people eating the bloated rotting carcasses of dead horses and the worn leather ripped off chairs and saddles. Rodriguez gave away his canopy and bed linen, three tunics and one set of his clothes so that the 'most miserable' amongst the starving, particularly the women, could cover up their naked, emaciated bodies. The worst aspect was that the few remaining able-bodied men had fled, abandoning their wives and children and allowing their houses and plots of land to be reduced to ruins because their cabeza de barangay had whipped them without mercy to collect taxes they were unable to pay.

From various civil and ecclesiastical documents we also learn that in 1802 typhoons once again wreaked havoc in the Cagayan Valley, leaving residents without water and food, and many without houses after the typhoon caused the Rio Grande to overflow its banks and carry them away. The great river inundated the rice fields and destroyed the harvest. A month later, a second rain-bearing typhoon swept away the little remaining palay. Fr Francisco Munoz OP testified on 30 October 1802, in Lal Lo, that the successive storms and floods of 15 September and 10 October had caused so much destruction to the fields that farmers could not give the missionaries their stipend of rice, nor could they, as a consequence, send grain for the maintenance of the troops in the capital of Lal Lo, let alone feed themselves.

Floods often hampered the efforts of Spanish military personnel to reach the worstaffected areas, with roads and tracks either washed away or cut off by rising waters and debris. ${ }^{44}$ More than a century later, such flood-prone conditions still had not changed-except that the approaching storm was reliably forecast and the residents along the river were warned via the telegraph by the Weather Bureau in Manila. Nevertheless, when the cyclonic storm tore through the communities of Isabella and surrounding smaller areas on 3 December 1936, it left a trail of destruction as

\footnotetext{
43 ibid.

44 Miguel Selga SJ, Meteorological Note 39, 'Los baguios y avenidas del Valle de Cagayan', Meteorological Bulletin (June 1939): 140; Vizente Escalante a Gobernador Capitan General, 15 September 1802, Ereccion de Pueblos Cagayan 1751-1847. F.257-268b. PNA.
} 
extreme as the typhoon and floods of 1802 . The indirect destruction due to flooding caused by the storm was greater than its direct impact because of the slow-moving winds swirling around the eye wall, which dumped heavy rains over the sources of the Cagayan River, before moving into the China Sea. Intense suffering and hunger were reported everywhere along the river for months. ${ }^{45}$

In July 1972, a series of terrible weather events affected Pampanga and neighbouring provinces. The typhoon-induced catastrophes, from which Pampanga, Tarlac, Quezon, Camarines Norte and Bulacan were still reeling many months later, dwarfed any similar disasters in recent times. Successive extreme typhoons, Eding and Gloring, triggered massive floods that damaged crops and left tens of thousands of marooned families exposed to starvation and disease. ${ }^{46}$ Relief missions could not reach Bulacan. ${ }^{47}$ Those who were able to make it to relief centres received food, some of them getting more than their emergency needs, to the prejudice of other starving flood victims. Massive problems faced the people of central Luzon as relief goods, intended for more distant areas, were virtually waylaid. In the towns of Pampanga and Bulacan closest to Manila, angry mobs of hungry people demanded rice be unloaded from trucks to alleviate the suffering. In the neighbouring province of Pangasinan, 250,000 people in 45 towns and two cities had been rendered homeless. ${ }^{48}$ More than 50,000 families were close to starvation in Pangasinan, while thousands came down with influenza in Pampanga, and various other respiratory and intestinal diseases were reported. ${ }^{49}$

Such scenes, a grim reminder of earlier centuries, provide a graphic illustration of the powerful forces of nature combining to demonstrate just how severe poverty is for people who lack sustenance in late twentieth-century central Luzon. A Marcosled government, accustomed to seeing frequent suffering and disaster, had quickly recognised the enormous scale of the 1972 catastrophe for the entire Luzon region and began relief efforts to stave off severe food shortages. But it did not attempt to directly resolve the basic problem of reforming the human institutions responsible for famine and starvation, because the government itself was part of the problem. As in the seventeenth century, inhabitants of the central Luzon flood plain in 1972 had to grapple with the realities of recent extreme weather as well as the social impacts of the wealth disparity.

45 Meteorological Bulletin for December 1936 (Manila: Weather Bureau, 1936), 239.

46 'Big howler tarries floods rampage', Manila Bulletin, 11 July 1972; 'Floods hit Luzon areas', Daily Mirror,

11 July 1972.

47 'Epidemic outbreak', Manila Times, 25 July 1972.

48 'Rains, floods paralyse CL, Manila area', Manila Times, 21 July 1972.

49 ibid. 


\section{Famine and the global economy}

Norman Owen, in his book about how the abaca crop drew the people of Bikol into the global economy, lists nine major typhoons and one drought (1804) between 1796 and 1845 that culminated with the typhoon and famine of $1845 .{ }^{50}$ Starvation followed in the wake of the typhoon and floods that hit Camarines Sur and Albay at the start of November 1845. Roads, houses, public buildings, livestock and crops were destroyed on an unprecedented scale. The reports of the military-political governor and alcalde mayor of Camarines Sur and Albay respectively, after touring areas ravaged by the typhoon and floods, likened the devastation to that seen in a war zone.

The subsequent flood damage to the rice crop had led to the rapid destitution and death of Bikolaños. Having never experienced scarcity quite like this before, many became ill and died from eating rotten taro, which, under normal circumstances, they would have ignored. Some desperate survivors died after drinking contaminated water and eating the decaying meat of drowned farm animals; victims probably of gastroenteritis. ${ }^{51}$ The deadly state of affairs in the provinces of Albay and Camarines and the escalating effects of this calamity on the rapidly rising price of palay compelled the Manila authorities to dispatch rice shipments at the expense of the caja de comunidad, to alleviate the food shortage and stave off famine.

I now want to fast forward to 'Black Tuesday', 13 October 1970, when Typhoon Sening completely destroyed Kabikolan. The typhoon generated landslides, floods, flash floods and 15-foot waves that caused terrified coastal dwellers to flee inland. When Sening finally moved on to pound Camarines Norte and Quezon, Kabikolan lay prostrate. As in 1845, the flattened province remained cut off and isolated from the rest of the country because electric lines, post office booster antennas and communication towers had toppled in the driving rain and wind. The prices of basic commodities skyrocketed and thousands of miserable and starving people sheltered in makeshift hovels along the major highway and roads. ${ }^{52}$ Thousands of families had been either displaced or rendered destitute and hungry in less than 24 hours. In Naga, there were justifiable fears of an epidemic outbreak abetted by starvation. ${ }^{53}$

In the 1980s and 1990s, southern Luzon continued to experience widespread havoc wreaked by typhoons and floods-disasters, natural and man-madedemonstrating why this part of Luzon and the island of Samar are sometimes called

50 Owen, Prosperity without Progress, 73, 80, 109, 111, 178, 190; Owen, 'A subsistence crisis in the provincial Philippines 1845-1846?

51 No. 943, El Gobierno Militar y Politico de la Provincia de Camarines Sur a Senor Gobernador y Capitan General de Filipinas, 6 November 1845. Calamidades Publicas 1845-1845, fol. 19-21. PNA.

52 Jose V. Barrameda Jr., 'The 13th of October, Black Tuesday', in Graphic, 4 November 1970.

53 ibid. 
the unlucky provinces. In January and February 1994, five successive typhoons that hit the archipelago affected vast areas of southern Luzon, the Bikol region, the whole of the Visayas and north-eastern Mindanao. ${ }^{54}$ More than 3.7 million people were affected, 600,000 of whom were rendered homeless, living in evacuation centres or makeshift shanties built from the debris of destroyed homes. Typhoon damage to agricultural crops was enormous. Some 100,000 were left starving. The World Food Programme supplied food in Mindoro Oriental, Marinduque, Camarines Norte, Camarines Sur, Catanduanes and Iloilo, as part of a massive rescue and relief effort launched by the government of the Philippines. ${ }^{55}$

But hunger continued to stalk various parts of the country. The following November, the Philippine Government stated that 75 per cent of the country had been declared in 'a state of calamity' because of the national fears of escalating food shortages and soaring inflation..$^{56}$ Another series of natural disasters, including Super Typhoon Angela, saw the doubling of rice prices after major relief mishaps, including poor distribution. The spectre of starvation loomed once again the following year in the worst affected regions of southern Luzon. Village heads and rescue workers reported how high winds and columns of water had swept away people, livestock, houses and ready-to-harvest crops. Tens of thousands were left homeless and hungry, their houses flooded or flattened, as Super Typhoon Angela destroyed rice and coconut crops worth millions of dollars. ${ }^{57}$ The government was forced to import more than 200,000 tons of rice in the aftermath of the super typhoon to avert a major famine.

\section{Food scarcity, rural unrest and migration}

Food scarcity and epidemics exacerbated societal group inequality, causing pillage, plundering and social unrest at a time anti-colonial resistance movements came into being. Across the centuries, it was the Visayas, particularly Samar and Leyte, that appear to have experienced small-scale wars with the recurring passage of typhoons. In October and November 1601, a strong typhoon struck the Jesuits' Leyte Mission and destroyed the town, churches and fields, along with crops, fruit trees and other sources of food. A babaylan, a female shaman, attempted to influence the victims' minds about the spiritual meaning of the alleged link between the storm, the outbreak of the famine and the presence of the 'black robes', or Jesuits, in their midst. In response to the spate of disasters, the babaylan preached to her people that

54 Philippine Red Cross, Information Bulletin, World Food Programme 958, 16 March 1994.

55 ibid.

56 'Philippine calamities hit stock market', Financial Times [London], 16 November 1995.

57 '250 dead as typhoon devastates Philippines', Toronto Star, 11 November 1995. 
the diwata (the native god) was angry at what the Jesuit fathers were teaching and consequently it inflicted punishments of death, destruction and famine upon them by sending the typhoon. ${ }^{58}$

Samar and Leyte suffered unmercifully in the Philippine-American War as the new century dawned. Low-intensity warfare was waged on both islands, villages and fields were routinely torched, and an infamous order was issued to kill all the inhabitants of Samar who were over 10 years of age. ${ }^{59}$ War worked in combination with typhoons and drought to ravage Samar and Leyte in the first decade of the twentieth century. Thousands went hungry.

Eastern Samar was one of the poorest regions of the Philippines, constantly beset by turmoil and disaster. From the vantage point of late nineteenth-century Manila, this part of the eastern Visayas required careful control, both by the Spanish and later the American administrations. In 1884, Spanish armed forces crushed a millennial rebellion triggered by widespread hunger and the outbreak of a severe cholera epidemic near Gandara. ${ }^{60}$ Two years later, in 1886, a new hills-based movement called Dios Dios, spawned by the same miserable conditions, held power in Samar for more than 20 years. The Dios Dios came to be called pulahanes, from their wearing red garments. Although their power waxed and waned, widespread famine and a cholera epidemic in the 1880s boosted the pulahanes' ranks, representing the Samareńos' deprivation and disempowerment. The pulahanes' appeal to supernatural means was accepted as part of their armed struggle armoury. The tensions existing between the Samareños and the Spanish Government became even more acute under American rule. Both sides were on the defensive, waiting for each other to strike pre-emptively, as Samar was to play a central role in the Philippine-American War of 1899-1902.

The typhoon of 25 September 1907 destroyed 5,000 homes and ruined the hemp crop, raising prospects of another famine. The governor-general in Manila acknowledged in 1928 that 20 years after American forces had turned Samar into a 'howling wilderness', farmers there were still having to spend more on food than they were earning from the export of their cash crops of abaca and coconuts. The governor-general wanted more resources put directly in the Samareños' hands to combat typhoons and famines. Guaranteeing better nutritional standards and access to local and regional markets for farmers was a more secure and sustainable

58 For a cogent discussion of the resistance of female religious leaders against early Spanish rule see Carolyn Brewer, Shamanism, Catholicism and Gender Relations in Colonial Philippines, 1521-1685 (Aldershot: Ashgate, 2004); Manuel Artigas y Cuerva, Reseña de la provincia de Leyte estudio histórico bio-bibliográfico, trans. and ed. Rolando O. Borringa and Cantius J. Kobak OFM, as The Colonial Odyssey of Leyte (1521-1914) (Quezon City: New Day Publishers, 2006), 113.

59 Borringa and Kobak, The Colonial Odyssey of Leyte (1521-1914), 124.

60 Cruikshank, Samar 1768-1898, 201. 
way of alleviating famine and eradicating poverty in Samar. In 1928, the governorgeneral noted that Samar stood out as one of the most appalling areas, where typhoons aggravated an already difficult situation:

and it is probably due to this fact that the inhabitants have never been able to pull themselves out of a very low standard of physical welfare. In many districts the people are habitually undernourished, and they constantly lack the vigor and initiative necessary to meet such catastrophes. Therefore, it is of vital importance not only to relieve the suffering caused by this typhoon, but, if possible, to do it in a way which will help to render the suffering provinces better able to take care of themselves in the future. ${ }^{61}$

By the late 1880s, as well as spawning millennial movements in Samar, droughtrelated food shortages and famines produced a resurgence of folk messianism throughout the Visayas and forced thousands of peasants and tribal peoples to move into the mountainous interiors of Panay, Negros, Samar and Leyte. ${ }^{62}$ Babaylaninspired flight became a form of risk-spreading mechanism designed to overcome food shortages resulting from consecutive bad harvests and global price shocks. Hungry, indebted Visayan farmers simply settled on land in the rugged interior, well beyond the reach of Spanish or later American authority. These farmers believed anyone had the right to settle on virgin land, particularly in the Visayas, where a traditional manner of coping with famine and drought has been to move on. These moves were sometimes voluntary, and at other times involuntary, depending on the character of drought-related, life-threatening situations. The migration of starving peasant populations signified a turn towards autonomy and self-determination.

Prospects remained grim in the aftermath of the famines in 1878-79 and 1902-03. Drought-stricken Visayan peasants refused to risk staying at home, where they would inevitably starve. When the drought burden in the Visayas grew unsupportable, a more mobile peasantry joined with autonomous, armed insurgents and folkmessianic movements that challenged the power of both Spanish and American colonial administrators. ${ }^{63}$ Seen from a colonial standpoint, the changes wrought among former debt-bonded wage labourers and immigrant sharecroppers looked irreversible and foreboding. After the great famines of 1878-79 and 1885, colonial policies had failed to prioritise food security, choosing to concentrate on trade

61 Annual Report of the Governor General of the Philippine Islands 1928 (Washington, DC: Government Printing Office, 1930).

62 Angel Martinez Cuesta, History of Negros (Manila: Casalinda, 1980), 253, 259-61, 378-9, 400, 412-13; Alfred W. McCoy, 'Sugar Barons: Formation of a Native Planter Class in the Colonial Philippines', The Journal of Peasant Studies 19, nos 3-4 (April-July 1992): 106-41, 109-14; Davis, Late Victorian Holocausts, 94-7; Violeta Lopez-Gonzaga, Land of Hope, Land of Want: A Socio-Economic History of Negros (1571-1985) (Manila: Philippine Historical Society, 1994), 105-10.

63 Cuesta, History of Negros, 253, 259-61, 378-9, 400, 412-13; McCoy, 'Sugar Barons', 106-41, 109-14; Davis, Late Victorian Holocausts, 94-7; Lopez-Gonzaga, Land of Hope, Land of Want, 105-10. 
liberalisation and commerce at a time when people in the Visayas and Luzon were starving. There were no policy structures to adequately sustain rural livelihoods or access to resources and markets and concomitant entitlements and incomes.

The peasants and cultivators who moved to the interior of islands like Panay, Negros or Samar took new lands into their own control. Without that unbridled access to interior lands there was no lasting solution to hunger. However, they soon came under different pressures, with outbreaks of localised fighting and sporadic American military actions. Thousands of these squatters were again reduced to begging for food or eating roots and grass.

\section{Conclusion}

Throughout the course of this paper, I have presented the causes and consequences of food shortages and famines and the relationship between climatic and weather factors, especially in relation to typhoons, floods and drought, and food supply. I have provided a definition of famine and then shown how monocrop agriculture, globalisation and political corruption can exacerbate an already hazardous situation. In examining famines over time, I have pointed out the structural links between food shortages, the nature of Filipino peasant societies and the weather factor by discussing the importance of rice to the Filipino diet. I have introduced personal stories from people who were in geographical areas directly affected by repeated typhoons, famine and corruption, and the societal group inequality and loss of entitlements that resulted. In digging deeper into the impact of food scarcity in particular geographical areas, I have highlighted the way rural unrest and revolutionary and millennial movements grew from such untenable situations.

Poor Filipino farmers have been doing it tough for the past several decades because of extreme weather, and there are no signs of it abating. In central and southern Luzon, and the central and eastern Visayas, there has been a constant struggle, with the forces of nature and global capital, to balance escalating production costs and tenancy arrangements against diminishing incomes and livelihoods, and conditions are worsening. That the weather and climate should turn against these agriculturalists with such venom is a blow from which many have found it increasingly difficult to recover, as they face growing uncertainty about their future on the land. Agriculture has reached a lamentable state in various parts of the country and if these conditions of deprivation and social inequality continue to persist in certain areas of southern Luzon, Negros and northern Mindanao there will be periodic starvation, if not famine. 
This text is taken from International Review of Environmental History, Volume 4, Issue 2, 2018, edited by James Beattie, published 2018 by ANU Press, The Australian National University, Canberra, Australia.

doi.org/10.22459/IREH.04.02.2018.04 